\title{
Farmers' Knowledge of Potato Viruses and Management Strategies in the Western Highlands of Cameroon
}

\author{
Temfack Deloko Dély Carlos' , Achiangia Patrick Njukeng1, Anoumaa Mariette1, \\ Chofong Gilbert Nchongboh1,2, Djomo Simé Hervé1, Lontsi-Demano Michel ${ }^{3}$, Fonkou Théophile ${ }^{1}$
}

${ }^{1}$ Research Unit of Applied Botany, University of Dschang, Dschang, Cameroon

${ }^{2}$ Julius Kuehn Institute, Institute of Epidemiology and Pathogen Diagnostics, Braunschweig, Germany

${ }^{3}$ Research Unit of Applied Biology and Ecology, University of Dschang, Dschang, Cameroon

Email: carlos_deloko@yahoo.com

How to cite this paper: Temfack, D.D.C. Achiangia, P.N., Anoumaa, M., Chofong, G.N., Djomo, S.H., Lontsi-Demano, M. and Fonkou, T. (2021) Farmers' Knowledge of Potato Viruses and Management Strategies in the Western Highlands of Cameroon. Open Journal of Applied Sciences, 11, 818831.

https://doi.org/10.4236/ojapps.2021.117060

Received: June 3, 2021

Accepted: July 27, 2021

Published: July 30, 2021

Copyright () 2021 by author(s) and Scientific Research Publishing Inc. This work is licensed under the Creative Commons Attribution International License (CC BY 4.0).

http://creativecommons.org/licenses/by/4.0/

\begin{abstract}
Potato (Solanum tuberosum L.), important staple food and a source of income to small-scale farmers, is mostly cultivated in Cameroon in the Western Highlands. Production constraints are exerted on this crop by many pathogens including viruses responsible for considerable yield losses. This study aimed at assessing the perception of farmers on the virus diseases that can affect potatoes, and to identify the control methods adopted against them. A semi-structured survey was carried out among 230 farmers in 24 villages of the Western Highlands zone of Cameroon. Out of these farmers, $80.87 \%$ had never heard of potato viruses. Those having pre-knowledge about potato viruses were $19.13 \%$. Among the latter, $16.52 \%$ had heard of potato viruses and transmission mode during capacity building workshops while $2.61 \%$ didn't know about the means of transmission. Insect control is essentially chemical (100\%). However, few farmers use biological methods such as intercropping (7.39\%) and application of plant extracts (4.78\%) to control insects. Twelve plant species, belonging to nine families, were mentioned for insect control. In addition to plants, farmers also use wood ash and rabbit urine for insect control. These results show the knowledge gap possessed by farmers with respect to potato viruses and their transmission mode. It is thus speculated that this spans to other crops in Cameroon settings. This finding can serve as a base and a working document for policymaking to ameliorate teaching, research and devilment related to plant viruses for better sustainable food production.
\end{abstract}

\section{Keywords}

Farmers Knowledge, Virus Control, Potato, Cameroon 


\section{Introduction}

In Cameroon, potato is grown in six of the ten regions of the country: West, North-West, South-West, Littoral, Adamaoua and Far North. The West and the North-West regions account for more than $80 \%$ of this production annually. Potato (Solanum tuberosum L.) refers both to the plant and the edible tuber. It is one of the most important industrial crops [1]; the starch-rich tubers are mainly used for food and feed [1]. The expected yield of potatoes is estimated at $25 \mathrm{t} / \mathrm{ha}$ in Cameroon [2]. However, that yield remains below average recording approximately 8 - $9 \mathrm{t} / \mathrm{ha}$. Myriad of biotic and abiotic factors can be raised to explain the low yield of potatoes in Cameroon. The climatic and ecological diversity that Cameroon possesses is not only favorable to the growth and development of a varied number of plant species but also conducive to the proliferation of many pathogens [3], which are responsible for causing many diseases that attack plants including potatoes and reduce productivity. Among these causal agents, local and resource-poor potato farmers in Cameroon are constantly faced with late blight and wild diseases. They have developed a trend of going for chemicals against such diseases. On the other hand, this attack is not only limited to fungal and bacterial diseases but extended to viruses [4]. On a global perspective, RNA, DNA viruses (more than 50) and viroid (one) are known to infect potato some of which can persist in the host plant, some integrate in the host genome and transmitted via cell lines and by several vectors including beetles, thrips, whiteflies, leaf hopper, aphids, psyllids, spongospora, nematodes and fungi [5]. These infectious entities use potato cellular machinery, while contributing to the disruption of its physiological processes, and causing significant yield losses [6]. Relatively, very few plant virologists are in Cameroon with less attention paid to plant viral diseases. Here, we hypothesized that a high proportion of potato farmers have scanty knowledge about plant viruses. The present study was conducted to assess the farmer's knowledge about potato viruses, their mode of transmission and management. This finding may raise awareness to plant and help as a base of virus framework for research and development in Cameroon.

\section{Materials and Methods}

\subsection{Study Site}

This research work was focused on potato as it is one of the major economically important crops grown by many households in the Western Highlands of Cameroon. It is located between latitudes $4^{\circ} 54^{\prime}$ and $6^{\circ} 36^{\prime} \mathrm{N}$, and between longitudes $9^{\circ} 1^{\prime}$ and $11^{\circ} 24^{\prime} \mathrm{E}$ measuring a land surface area of 3.1 million hectares, including the West and the North-West regions of Cameroon.

At the initial stage, our research team interviewed local crop expert of several Agric Post Stations to collect informations that allowed us to identify the main localities of potato production. Through local extension officers we then choose the administrative units (Divisions, Sub-Divisions and Villages), where potatoes are most produce. This study was conducted between January 2019 and May 
2020, in 7 divisions of the agro-ecological zone of the Western Highlands of Cameroon covering 24 villages (Table 1 ).

\subsection{Sampling Method and Data Collection}

The farmers surveyed were the ones largely in charge for plantations with an area of at least $1000 \mathrm{~m}^{2}$, and directly involved in day to day management of the farm activities.

A survey was carried out using a semi-structured questionnaire in 12 sub-divisions of the Western Highland zones of Cameroon.

Table 1. List of villages, Sub-divisions and divisions where respondents were targeted.

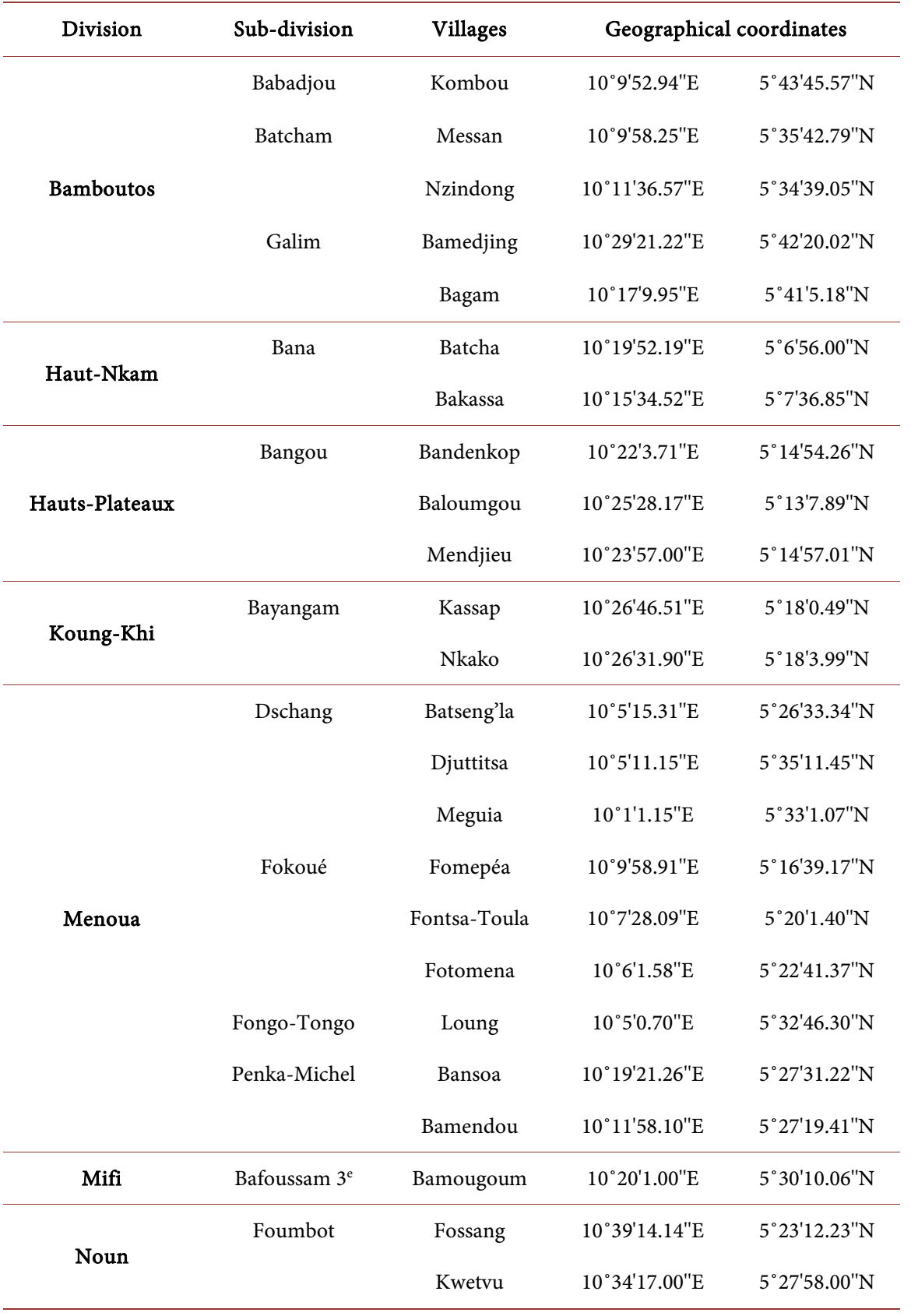


A total of 230 potato farmers were randomly selected. So, twenty (20) farmers per sub-division were surveyed, with the exception of Foumbot where only ten (10) farmers were surveyed due to the low number of potato farmers found there. The number of respondents varied from one village to another per subdivision, due to the unavailability of farmers to great time to answer the questionnaire. Data were collected on socio-demographic characteristics (gender, age, level of education, matrimonial status), seed management, nematodes control, cultivated varieties, knowledge of potato viruses and methods of insect control. The survey was carried out using a smartphone with ODKCollect v-1.11.3 software in which the questionnaire was previously integrated.

\subsection{Data Processing}

Collected responses to the questionnaires were loaded on the ODK Tools kits platform and data exported to Excel2007 worksheet. Here, the calculation of the percentage of adoption of the practices by the farmers was done. The chi-square test $\left(\chi^{2}\right)$ was used to evaluate the significance at the $5 \%$ probability threshold, using the MedCalc v15.8 software.

\section{Results and Discussion}

\subsection{Characteristics of Farmers}

As per collected data, the farmers were stratified based on the general socio-demographic characteristics (gender, age, study level and marital status). Out of the 230 interviewed, $56.96 \%$ were men, whereas $43.03 \%$ were women $\left(\chi^{2}=2.970\right.$; DF $=1 ; \mathrm{p}=0.0848)$. Most of the farmers aged between $30-50$ (46.52\%) followed by those with age greater than 50 representing $32.61 \%$. The youth are less engaged in potato production with the age range between 15-30 years of age accounting for $20.87 \%$. According to the chi-square test $\left(\chi^{2}=33.652\right.$; $\left.\mathrm{DF}=2 ; \mathrm{p}<0.0001\right)$, there was a significant difference between the different age groups (Table 2). Kateka et al. [7] found higher percentage for the same age group, among potato farmers in Malawi.

Majority of the farmers acquired formal secondary education (50.43\%), 84.78\% married and $15.22 \%$ were single $\left(\chi^{2}=43.999 ; \mathrm{DF}=1 ; \mathrm{p}=0.0001\right)$.

\subsection{Seed Management}

\subsubsection{Origin and Category of Seeds}

The source of planting material is a paramount concern and essential for potato virus studies. Our finding shows that $60.87 \%$ of farmers acquired their seeds from individual conservation from previous seasons to be used for the upcoming season. In a decreasing percentage, 54.35\%, 28.26\% 16.96\%, 8.26\% $2.17 \%$ and $2.17 \%$ obtain seeds from the markets, seed multipliers, farmer-to-farmer exchange, Institute of Agricultural Research and Development (IRAD), Ministry of Agriculture and Rural Development (MINADER) and imported respectively $\left(\chi^{2}\right.$ $=250.058 ; \mathrm{DF}=6 ; \mathrm{p}<0.0001)$. The high frequency of use of individually saved 
Table 2. Summarized date based on surveyed farmers per administrative division $(n=230)$ with relation to sex, age, educational level and marital status.

\begin{tabular}{|c|c|c|c|c|c|c|c|c|}
\hline & \multicolumn{8}{|c|}{ Administrative Divisions of the surveyed area } \\
\hline & Bamboutos & Hauts-Kam & Hauts-Plateaux & Koung-Khi & Menoua & Mifi & Noun & \\
\hline Variables & \multicolumn{7}{|c|}{ Number of respondents surveyed per divisions (percentage) } & Total (\%) \\
\hline \multicolumn{9}{|c|}{ Sex } \\
\hline Male & $44(19.13)$ & $4(1.74)$ & $6(2.61)$ & $18(7.82)$ & $49(21.31)$ & $8(3.48)$ & $2(0.87)$ & $131(56.96)$ \\
\hline Female & $16(6.95)$ & $16(6.95)$ & $14(6.09)$ & $2(0.87)$ & $31(13.48)$ & $12(5.22)$ & $8(3.48)$ & $99(43.04)$ \\
\hline \multicolumn{9}{|c|}{ Age group } \\
\hline$[15-30[$ & $29(12.61)$ & $00(00)$ & $2(0.87)$ & $2(0.87)$ & $14(6.09)$ & $00(00)$ & $1(0.43)$ & $48(20.87)$ \\
\hline$[30-50[$ & $14(6.08)$ & $10(4.35)$ & $10(4.35)$ & $16(6.95)$ & $40(17.4)$ & $10(4.35)$ & $7(3.04)$ & $107(46.52)$ \\
\hline [50 and more[ & $17(7.4)$ & $10(4.35)$ & $8(3.47)$ & $2(0.87)$ & $26(11.30)$ & $10(4.35)$ & $2(0.87)$ & $75(32.61)$ \\
\hline \multicolumn{9}{|c|}{ Educational level } \\
\hline Unschooled & $4(1.74)$ & $00(00)$ & $00(00)$ & $00(00)$ & $4(1.74)$ & $2(0.87)$ & $00(00)$ & $10(4.35)$ \\
\hline Primary education & $27(11.74)$ & $10(4.35)$ & $6(2.60)$ & $2(0.87)$ & $17(7.4)$ & $8(3.48)$ & $5(2.17)$ & $75(32.61)$ \\
\hline Seconary education & $27(11.74)$ & $7(3.04)$ & $9(3.91)$ & $15(6.52)$ & $45(19.57)$ & $8(3.48)$ & $5(2.17)$ & $116(50.43)$ \\
\hline Higher education & $2(0.87)$ & $3(1.30)$ & $5(2.17)$ & $3(1.30)$ & $14(6.10)$ & $2(0.87)$ & $00(00)$ & $29(12.61)$ \\
\hline \multicolumn{9}{|c|}{ Marital status } \\
\hline Single & $17(7.4)$ & $00(00)$ & $2(0.87)$ & $2(0.87)$ & $13(5.65)$ & $00(00)$ & $1(0.43)$ & $35(15.22)$ \\
\hline Married & $43(18.7)$ & $20(8.7)$ & $18(7.82)$ & $18(7.82)$ & $67(29.13)$ & $20(8.7)$ & $9(3.91)$ & $195(84.78)$ \\
\hline
\end{tabular}

seeds would be an asset for the spread of viruses, these because, farmers generally save their seeds in inappropriate conditions. In addition, respondents stated that they do not make any diagnosis to check the health status of saved seed for the present of viruses which equally holds for market sold seeds.

Potato farmers surveyed presented three categories of seed used including basic, certified and non-classified seeds. As summarized, $90.44 \%$ of these farmers use unclassified seed, $28.26 \%$ (certified seed) and 3.92\% use basic seed $\left(\chi^{2}=153.543\right.$; $\mathrm{DF}=2 ; \mathrm{p}<0.0001)$. The low frequency of use of basic seed could be justified by its high price. Indeed, these seeds are obtained by meristem cultivation and require a long production period. According to Ali et al. [8], virus eradication has been successful in many potato varieties through in vitro meristem culture.

\subsubsection{Seed Stock Duration (in Years) Handling and Treatment during Conservation}

Based on the respondent's feedback, $60.87 \%$ of potato farmers used seed stock saved from their produce from 3 - 6 years. A proportion of farmers $(32.17 \%)$ and $6.69 \%$ used stock from $0-3$ and 6 years more, respectively $\left(\chi^{2}=77.476\right.$; DF $=2$; $\mathrm{p}<0.0001)$. The farmers interviewed explained this by the lack of good quality seeds, which is however related to a shortage of seeds production stations. In addition, good quality seeds are sold at very high prices. Unfortunately, the long-term 
multiplication of infected seeds favors the development of viruses because with each new generation, new viruses of the same or different species may be added to the existing ones, hence increasing the viral load in the plants [9]. According to Thomas-Sharma et al. [10], long seeds storage leads to an accumulation of pathogens that reduce seed vigor and yield.

Handling and treatment of planting material during its conservation was analyzed and data showed that 99 farmers recording $43.04 \%$ performed seed treatment with men constituting $32.61 \%$ (75) and women $10.43 \%(24)\left(\chi^{2}=17.987\right.$; $\mathrm{DF}=1 ; \mathrm{p}<0.0001)$. On the other hand, $131(56.96 \%)$ do not practice seed treatment $\left(\chi^{2}=2.970 ; \mathrm{DF}=1 ; \mathrm{p}=0.0848\right)$. Although there is no significant difference, the high percentage of farmers who do not treat seeds could be explained by the lack of knowledge of seed saving methods. This high rate of the male gender could be linked to the fact that potato is produced by men for it is considered a business; the majority of men are heads of households and are responsible for providing needs for their families. Thus, they take time to treat their seeds in order to guarantee production in the next seasons and/or to keep the seeds in good condition for marketing. However, the low percentage of women is said to be related to the fact that most women generally grow potatoes for consumption only.

Horizontal transmission allows viruses to pass from one plant or seed to another with the help of vectors. To limit or reduce this type of transmission, vector control is encouraged. Among the 99 farmers who treat seeds, $98.98 \%$ (98) use synthetic insecticides, $18.18 \%$ (18) use fungicides and $2.02 \%$ (2) use alternative methods $\left(\chi^{2}=88.497 ; \mathrm{DF}=2 ; \mathrm{p}<0.0001\right)$. Insecticide is however the product most used by the farmers surveyed. This high frequency of insecticide use would only be effective against viruses that are transmitted in a persistent manner, as these require a recognition relationship between the host and the vector [11]. Thus, the use of insect repellants and/or anti-insect nets could be crucial for the control of non-persistent transmissible viruses [12]. Similarly, the use of fungicides for seed treatment should not be neglected. Indeed, according to Andika et al. [13], many fungi, in addition to being plant pathogenic for potatoes, are also vectors of viruses.

The frequency of seed treatment of potatoes during storage shows that $61.62 \%$ (61) of farmers treat seed once during the entire shelf life, while $31.31 \%$ (31) and $7.07 \%$ (7) treat their own once a month and twice a month respectively $\left(\chi^{2}=\right.$ 33.934; $\mathrm{DF}=2 ; \mathrm{p}<0.0001)$. The low frequency of treatment recorded among the majority of farmers during this study is also one of the causes that may favor the spread of vector-transmissible viruses. Indeed, the insecticide treatment should be renewed regularly in order to maintain the toxicity of the environment [14] where the seeds are stored.

With the exception of vector transmission, which can be controlled by pesticides, mechanically transmitted viruses can be transmitted from an infected tuber to a healthy tuber by simple contact [1] during storage. To overcome this 
problem, the temperature of the seed storage medium should be lowered to the recommended level $\left(4^{\circ} \mathrm{C}-6^{\circ} \mathrm{C}\right)$, followed by a relative humidity of $80 \%$ [15]. Low storage temperatures and high relative humidity would thus slow down virus activity and further limit the possibilities for mechanical transmission.

\subsubsection{Plant Species Used in Seed Treatment}

Among the different farmers surveyed, only $0.87 \%$ (2) resort to seed treatment using plants derivatives. The plant used for this purpose is Lantana camara, which is used in various forms. These farmers use it in the form of aqueous extracts or cut it and place on the potato seeds. They admitted that they find this way of treating the seeds satisfactory because they combine it with a small quantity of synthetic insecticide and it is done at a lower cost. The plant has fungicidal, nematicidal and insecticidal properties [16].

\subsection{Nematodes Control}

Nematodes such as the potato golden nematode (Heteredera rostochiensis) attack potato roots and cause yield losses. In addition to devastating potatoes, some nematodes are vectors for viruses in potato crops. This is the case of the nematodes such as Trichoorus sp. and Paratrichodorus sp. that transmit Tobacco rattle virus to potatoes [17]. However, it emerges from this study that no farmer surveyed practices phytosanitary treatment against nematodes; attitude that could be justified by the lack of information.

\subsection{Cultivated Varieties}

Figure 1 shows the different potato varieties grown by the farmers surveyed. Fifteen (15) potato varieties were identified during this study. However, the Dosa $(87.83 \%)$ and Désiré $(80.43 \%)$ varieties are the most widely grown, while the Juwel $(10.87 \%)$ and Spinta $(7.4 \%)$ varieties are the least grown. Several reasons have been put forward to explain this difference in the production rate of the different varieties. These include seed availability (54.35\%), yield (48.26\%), disease resistance $(42.17 \%)$, short cycle $(38.7 \%)$, early germination $(32.62 \%)$, consumer demand (19.57\%) and taste (12.61\%). Independently of the varieties, potatoes are subject to numerous attacks by pathogens, including viruses. Viruses account for almost half of the pathogens involved in emerging infectious crop diseases [18]; and their spread is linked to several factors including the susceptibility of the crop variety [19]. Lack of resistance to pests and diseases is known to be one of the major problems for potato cultivation in Cameroon [20]. Faced with the non-existence of virucides, the genetic heritage of certain potato varieties confers resistance to certain viruses [21]. Varietal resistance can also be acquired artificially. This process requires the search for resistance genes and their incorporation into potato genotypes. This is the case of the Rysto gene taken from Solanum stoloniferum which is grafted onto chromosome number 12 of the potato and which confers resistance to the different strains of Potato virus $Y$ (PVY) [22]. 


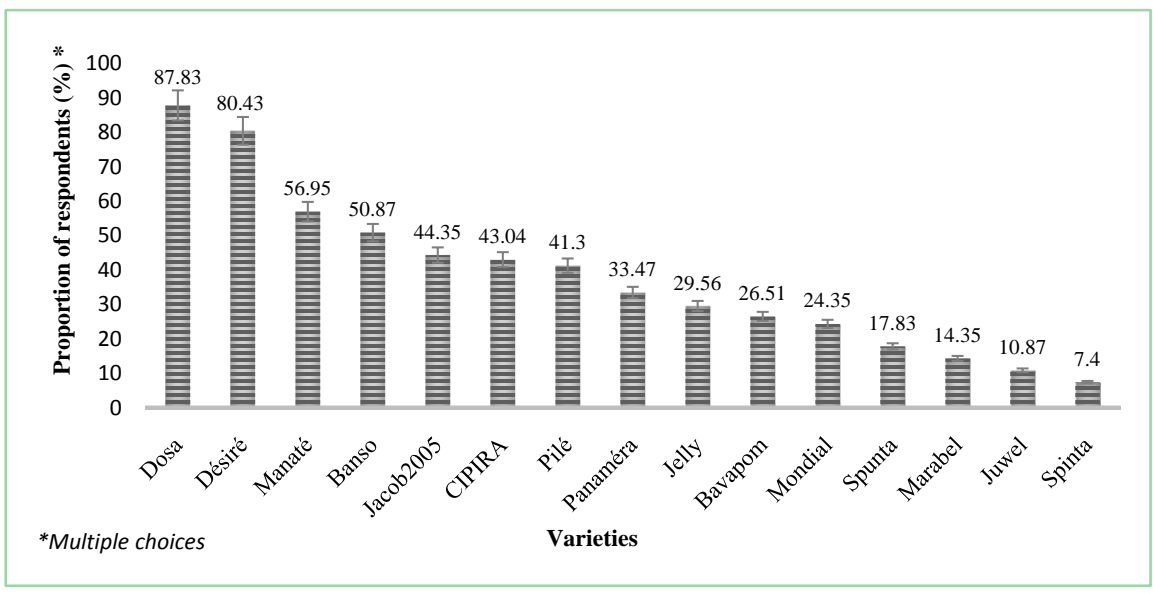

Figure 1. Bar chart representing the proportion farmers with varieties grown in the agro-ecological zone of the western highlands of Cameroon.

\subsection{Potato Viruses}

\subsubsection{Knowledge of Potato Viruses}

According to the knowledge of viruses, $80.87 \%$ (186) of the respondents have never heard of potato viruses, compared to $19.13 \%$ (44) who have heard of them $\left(\chi^{2}=60.943 ; \mathrm{DF}=1 ; \mathrm{p}<0.0001\right)$. This shows that very few farmers are aware of the existence of the viruses, as reported by Biao et al. [23]. However, farmers' lack of knowledge of viruses and vectors is believed to lead to their rapid spread in plantations [24]. Although some virus symptoms are almost identical to those of other pathogens, there are also symptoms that are easily differentiated, such as Potato leaf roll caused by Potato leaf roll virus. However, farmers tend to confuse all the symptoms of the different viruses with those caused by other pathogens, especially fungi (late blight) and bacteria (bacterial wilt). This lack of knowledge about viruses, combined with lack of symptom control, could thus be justified by a lack of training. According to Schreinemachers et al. [25], strategies to control viruses include training, which could increase farmers' awareness and knowledge of viruses, including disease identification, epidemiology and management.

Figure 2 shows the percentage of farmers' citations on virus knowledge according to level of education. The figure shows that $10.43 \%$ of respondents with knowledge of viruses have a secondary school education, while $6.53 \%$ have a higher school education and $2.17 \%$ a primary school education $\left(\chi^{2}=9.570 ; \mathrm{DF}=\right.$ $2 ; \mathrm{p}=0.0084)$. However, $40 \%, 30.43 \%$ and $6.09 \%$ of respondents without knowledge of viruses have respectively secondary, primary and higher levels of education; $4.35 \%$ are unschooled $\left(\chi^{2}=86.730 ; \mathrm{DF}=3 ; \mathrm{p}<0.0001\right)$.

The percentage of respondents' citation of where they heard about the potato viruses shows that, $86.36 \%$ of respondents heard about the viruses during training, $47.72 \%$ from researchers, $20.45 \%$ from reading, $9.09 \%$ from other farmers, $4.54 \%$ from teachers and $2.27 \%$ from heads of agricultural posts $\left(\chi^{2}=57.719 ; \mathrm{DF}\right.$ $=5 ; \mathrm{p}<0.0001)$. Thus, the level of study could not influence the knowledge of 


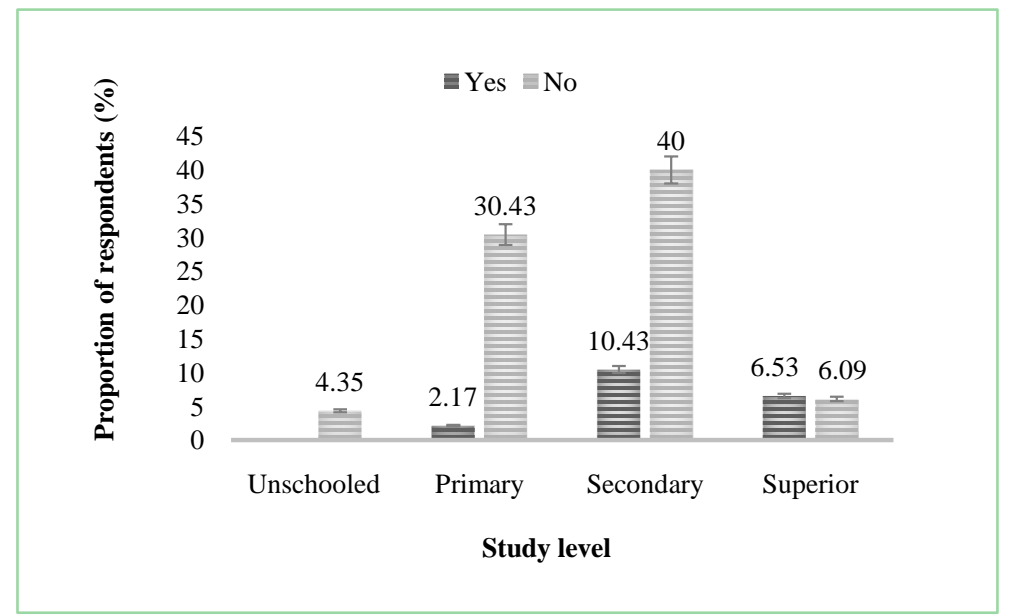

Figure 2. Bar chart representing the proportion farmers as function of educational level.

viruses. There is an urgent need for training programs to fill the lack of knowledge of farmers in various topics, in order to contribute to improvement of yield, as reported by Rahman et al. [26].

\subsubsection{Mode of Transmission of Viruses}

Knowledge of the mode of transmission of viruses and their life cycles is very important for disease prevention [29]. Among the 44 farmers who know about the existence of viruses, $38(16.52 \%)$ have ideas on the different modes of transmission. However, only 5 (2.17\%) of the farmers know about all modes of virus transmission (Figure 3). It therefore appears that very few farmers know the modes of transmission of potato viruses.

\subsection{Methods of Insect Control in Potato Farms}

Surveys have revealed that several control techniques are being adopted against insects in potato cultivation. $100 \%$ of farmers opt for chemical control, $77.83 \%$ for scrubbing, $70.44 \%$ for crop rotation, $63.91 \%$ for weeding, $15.22 \%$ for fallow, $7.39 \%$ for intercropping and finally $4.78 \%$ for the use of plant extracts $\left(\chi^{2}=\right.$ 312.779; $\mathrm{DF}=6 ; \mathrm{p}<0.0001)$. The use of chemicals is generally the main strategy of insects control on crops [27]. According to Mondedji et al. [28], African market gardeners mainly use synthetic products to reduce pest damage. However, their inappropriate use causes various drawbacks, including increased insect (pest and vector) resistance [29] which contributes to crop devastation and virus transmission.

Several reasons were given for the choice of different insect control techniques adopted by the surveyed farmers. Indeed, $84.35 \%$ do not know that plants have insecticidal and/or insect repellant properties; $12.61 \%$ do not know which plants are associated with potatoes for intercropping; and finally, 3.04\% talked of the unavailability of plant extracts. These results could thus justify the low proportions of intercropping and the use of plant extracts in insect control in the agro-ecological zone of the western highlands of Cameroon. 


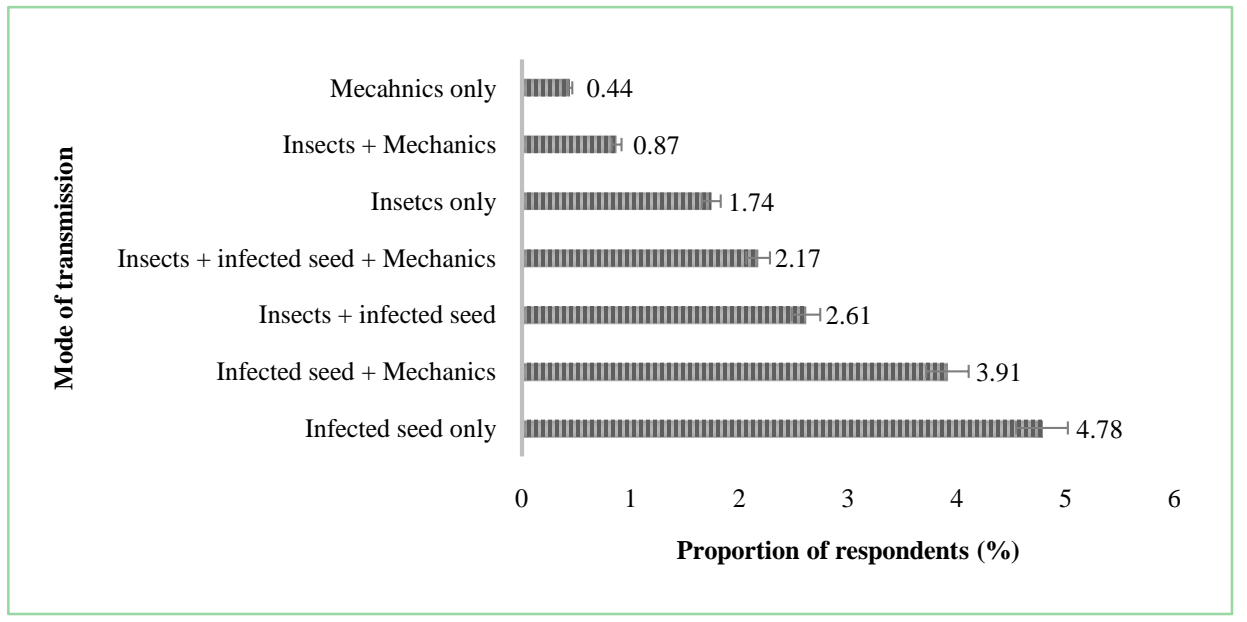

Figure 3. Bar chart representing the proportion farmer's perception of the modes of transmission of viruses.

\subsubsection{Synthetic Insecticides Used by the Respondents}

All the farmers surveyed use various combinations of synthetic insecticides. Among these insecticides, that with the trade name Cofresh 100 EC (69.13\%) was the most cited. It was followed by the Cicogne 360 EC (64.35\%), Parastar 40 EC (61.73\%) (Table 3).

\subsubsection{Plants Used for Insect Control}

Plant species used by farmers as plant extract for insect control. It emerges that eight (8) plant species were cited, and are among others: Chenopodium ambrosioides (3.91\%), Lantana camara (3.04\%), Azadirachta indica (2.61\%), Nicotina tobacum (1.74\%), Tephrosia vogelii (1.30\%), Tithonia diversifolia (1.30\%), Capsicum spp (0.87\%) and Carica papaya (0.43\%). According to the respondents' statements, the leaves of these plant species are finely ground and the extracts are sprayed onto potatoes. It should be noted, however, that some farmers use neem oil (Azadirachta indica) bought in markets. As for intercropping, four (4) plant species were cited by the farmers surveyed. These were $Z e a$ mays (5.65\%), Allium cepa (3.91\%), Allium porrum (3.04\%) and Allium sativum $(0.87 \%)$.

A total of twelve (12) plant species, belonging to nine (9) botanical families, were cited in the field of potato protection against insects. Many studies have already demonstrated the insecticidal and/or insect repellant effect of some of these plants. These include the species Allium cepa, Azadirachta indica, Carica papaya and Lantana camara [30] [31].

\subsection{Other Control Methods}

In order to destroy insects and all potato pests, $10(4.38 \%)$ farmers stated that they use different products and combinations of products for this purpose. These include: wood ash and rabbit urine. Many authors have already demonstrated the pesticidal effects of wood ash of some tree species [32]. 
Table 3. Summary of synthetic insecticides used by farmers surveyed.

\begin{tabular}{|c|c|c|}
\hline Trades names & Active ingredients & Percentage of respondents $(\%)^{*}$ \\
\hline Abamet $18 \mathrm{EC}$ & Abamectin $18 \mathrm{~g} / 1$ & 33.47 \\
\hline Acarius & Abamectin $18 \mathrm{~g} / 1$ & 40.43 \\
\hline Aceplant $40 \mathrm{EC}$ & Acetamiprid $40 \mathrm{~g} / \mathrm{l}$ & 48.26 \\
\hline Ampligo $150 \mathrm{ZC}$ & Lambda-cyhalothrin $50 \mathrm{~g} / \mathrm{l}+$ chlorantranilole $100 \mathrm{~g} / \mathrm{l}$ & 46.08 \\
\hline Area $50 \mathrm{EC}$ & Emamectine benzoate $10 \mathrm{~g} / \mathrm{l}+$ Lambda-cythalothrin $40 \mathrm{~g} / \mathrm{l}$ & 47.78 \\
\hline Ballecot $4.9 \mathrm{EC}$ & Lambda-cyhalothrin $50 \mathrm{~g} / \mathrm{l}$ & 47.87 \\
\hline BOMEC & Abamectin $18 \mathrm{~g} / \mathrm{l}$ & 35.21 \\
\hline Cicogne $50 \mathrm{EC}$ & Cypermethrin $50 \mathrm{~g} / \mathrm{l}$ & 43.91 \\
\hline Cicogne $360 \mathrm{EC}$ & Cypermethrin $360 \mathrm{~g} / \mathrm{l}$ & 64.35 \\
\hline Cofresh $100 \mathrm{EC}$ & Cypermethrin $80 \mathrm{~g} / 1$ + Imidacloroprid $20 \mathrm{~g} / \mathrm{l}$ & 69.13 \\
\hline Cyper-Sam 50 EC & Cypermethrin $100 \mathrm{~g} / \mathrm{l}$ & 57.83 \\
\hline Cyperfresh 100 EC & Cypermethrin $100 \mathrm{~g} / \mathrm{l}$ & 52.06 \\
\hline Cythrine 25 EC & Cypermethrin $25 \mathrm{~g} / 1$ & 55.65 \\
\hline Parastar $40 \mathrm{EC}$ & Imidacloroprid $20 \mathrm{~g} / 1$ + Lambda-cyhalothrin $20 \mathrm{~g} / \mathrm{l}$ & 61.73 \\
\hline Proclaim 019 EC & Emamectin-benzoate $19.2 \mathrm{~g} / 1$ & 42.17 \\
\hline Super $50 \mathrm{EC}$ & Cypermethrin $50 \mathrm{~g} / \mathrm{l}$ & 50.87 \\
\hline Tamega $25 \mathrm{EC}$ & Deltaméthrin $25 \mathrm{~g} / \mathrm{l}$ & 22.17 \\
\hline Tourbillon super $35 \mathrm{EC}$ & Lambda-cyhalothrin $15 \mathrm{~g} / \mathrm{l}+$ Acetamiprid $20 \mathrm{~g} / \mathrm{l}$ & 54.35 \\
\hline Viper 46 EC & Acetamiprid $16 \mathrm{~g} / 1+$ Indoxacarde $30 \mathrm{~g} / 1$ & 35.56 \\
\hline
\end{tabular}

${ }^{*}$ Multiple choice.

\section{Conclusion}

The concept of viral disease and its transmission are little known by potato farmers in the Western Highlands of Cameroon; only 19.13\% of farmers know of its existence. Insect control is essentially chemical and very few farmers use alternative methods ( $7.39 \%$ for intercropping and $4.78 \%$ for plant extracts). However, Chenopodium ambrosioides has been the most cited plant species in the fight against insects as a plant extract; while Zea mays has been the most for intercropping. Therefore, it emerges from this study that knowledge of potato viruses is not linked to the level of education, age or marital status, but rather to the training undergone by farmers. Faced with these results, it is imperative to train farmers with regard to potato virus diseases and their management, in order to help to improve yields.

\section{Acknowledgements}

We are very grateful to the potato farmers in the Western Highlands of Cameroon who accept to providing information to us during data collection.

\section{Funding}

This study received no external funding. 


\section{Conflicts of Interest}

The authors declare no conflicts of interest regarding the publication of this paper.

\section{References}

[1] Yardimici, N., Kilic, H.C. and Demir, Y. (2015) Detection of PVY, PVX, PVS, PVA and PLRV on Different Potato Varieties in Turkey Using DAS-ELISA. Journal of Agricultural Sciences, 17, 757-764.

[2] Yengoh, G. and Ardo, J. (2014) Crop Yield Gaps in Cameroon. AMBIO: A Journal of the Human Environment, 43, 175-190. https://doi.org/10.1007/s13280-013-0428-0

[3] Yengoh, G.T., Hickler, T. and Tchuinte, A. (2011) Agro-Climatic Resources and Challenges to Food Production in Cameroon. Geocarto International, 26, 251-273. https://doi.org/10.1080/10106049.2011.556756

[4] Gul, Z., Khan, A.A., Khan, A.U. and Khan, Z.U. (2013) Incidence of Potato Viruses in Different Districts of Khyber Pakhtunkhawa, Pakistan. International Journal of Phytopathology, 2, 32-36. https://doi.org/10.33687/phytopath.002.01.0045

[5] Bragard, C., Caciagli, P., Lemaire, O., Lopez-Moya, J.J., MacFarlane, S., Peters, D., Susi, P. and Torrance, L. (2013) Status and Prospects of Plant Virus Control through Interference with Vector Transmission. Annual Review of Phytopathology, 51, 177-201. https://doi.org/10.1146/annurev-phyto-082712-102346

[6] Sharma, P., Sahu, A.K., Verma, R.K., Mishra, R. and Gaur, R.K. (2013) Biological and Molecular Characterization of Potato virus Y Infecting Potato (Solanum tuberosum L.) in India. Asian Journal of Biological Sciences, 6, 257-264. https://doi.org/10.3923/ajbs.2013.257.264

[7] Kateka, S.Y., Kabambe, V., Lowele, M.W. and Nalivata, P.C. (2015) Production Practices of Potato (Solanum tuberosum L.) by Farmers in Mzimba District, Northern Malawi. African Journal of Agricultural Research, 10, 797-802. https://doi.org/10.5897/AJAR2014.9081

[8] Ali, M.A., Nasiruddin, K.M., Haque, M.S. and Faisal, S.M. (2014) Virus Elimination in Potato through Meristem Culture Followed by Thermotherapy. SAARC Journal of Agriculture, 11, 71-80. https://doi.org/10.3329/sja.v11i1.18376

[9] Rahman, M.S., Akanda, A.M., Mian, I.H., Bhuian, K.A. and Karim, M.R. (2010) Growth and Yield Performance of Different Generations of Seed Potato as Affected by PVY and PLRV. Bangladesh Journal of Agricultural Research, 35, 37-50. https://doi.org/10.3329/bjar.v35i1.5865

[10] Thomas-Sharma, S., Abdurahman, A., Ali, S., Andrade-Piedra, J.L., Bao, S. and Charkowski, A.O. (2016) Seed Tuber Degeneration in Potato: The Need for a New Research and Development Paradigm to Mitigate the Problem in Developing Countries. Plant Pathology, 65, 3-16. https://doi.org/10.1111/ppa.12439

[11] Yattara, A.A.A., Coulibaly, A.K. and Francis, F. (2014) Diversité et abondance des pucerons [Homoptera: Aphididae] et leur impact sur la dissémination des virus infectant la pomme de terre au Mali. Phytoprotection, 94, 1-7. https://doi.org/10.7202/1024719ar

[12] Fereres, A. and Raccah, B. (2015) Plants Virus Transmission by Insects. In: eLS, John Wiley \& Sons, Ltd., Chichester. https://doi.org/10.1002/9780470015902.a0000760.pub3

[13] Andika, I.B., Wei, S., Cao, C., Salaipeth, L., Kondo, H. and Sun, L. (2017) Phytopathogenic Fungus Hosts a Plant Virus: A Naturally Occurring Cross-Kingdom Viral Infection. PNAS, 114, 12267-12272. https://doi.org/10.1073/pnas.1714916114 
[14] Maroni, M., Fanetti, A.C. and Metruccio, F. (2006) Risk Assessment and Management of Cupational Exposure to Pesticides in Agriculture. Medicina del Lavaro, 97, Article ID: 4306437.

[15] Bentini, M., Caprara, C. and Martelli, R. (2009) Physico-Mechanical Properties of Potato Tubers during Cold Storage. Biosystems Engineering, 104, 25-32. https://doi.org/10.1016/j.biosystemseng.2009.03.007

[16] Begum, S., Wahab, A., Siddiqui, B.S. and Qamar, F. (2000) Nematicidal Constituents of the Aerial Parts of Lantana camara. Journal of Natural Products, 63, 765-767. https://doi.org/10.1021/np9903548

[17] Macfarlane, S.A. (2010) Tobraviruses-Plant Pathogens and Tools for Biotechnology. Molecular Plant Pathology, 11, 577-583. https://doi.org/10.1111/j.1364-3703.2010.00617.x

[18] Harahagazwe, D., Condori, B., Barreda, C., Bararyenya, A., Byarugaba, A.A., Kude, D.A., Lung'aho, C., Martinho, C., Mbiri, D., Nasona, B., Ochieng, B., Onditi, J., Randrianaivoarivony, J.M., Tankou, C.M., Worku, A., Schulte-Geldermann, E., Mares, V., Mendiburu, F. and Quiroz, R. (2018) How Big Is the Potato (Solanum tuberosum L.) Yield Gap in Sub-Saharan Africa and Why? A Participatory Approach. Open Agriculture, 3, 180-189. https://doi.org/10.1515/opag-2018-0019

[19] Jones, R.A. and Vincent, S.J. (2018) Strain-Specific Hypersensitive and Extreme Resistance Phenotypes Elicited by Potato virus $Y$ among 39 Potato Cultivars Released in Three World Regions over a 117-Year Period. Plant Disease, 102, 185-196. https://doi.org/10.1094/PDIS-06-17-0901-RE

[20] Deffo, V. and Demo, P. (2003) Adoption of Two New Potato Varieties in Cameroon: Progress and Constraints. American Journal of Potato Research, 80, 263-269. https://doi.org/10.1007/BF02855362

[21] Torrance, L.L., Cowan, G.H., McLean, K., MacFarlane, S., Al Abedy, A., Armstrong, M., Lim, T., Hein, I. and Bryan, G.J. (2020) Natural Resistance to Potato virus $\mathrm{Y}$ in Solanum tuberosum Group Phureja. Theoretical and Applied Genetics, 133, 967-980. https://doi.org/10.1007/s00122-019-03521-y

[22] Grech-Baran, M., Witek, K., Szajko, K., Witek, A.I., Morgiewicz, K., Wasilewicz-Flis, I., Jakuczun, H., Marczewski, W., Jones, J.D.G. and Hennig, J. (2020) Extreme Resistance to Potato virus $Y$ in Potato Carrying the Rysto Gene Is Mediated by a TIR-NLR Immune Receptor. Plant Biotechnology Journal, 18, 655-667. https://doi.org/10.1111/pbi.13230

[23] Biao, F., Afouda, L. and Koné, D. (2019) Prévalence des maladies virales du piment (Capsicum spp.) et perception des producteurs dans la commune de Malanville au Nord-Bénin. International Journal of Biological and Chemical Sciences, 13, 166-177. https://doi.org/10.4314/ijbcs.v13i1.14

[24] Wokorach, G., Edema, H. and Echodu, R. (2018) Sweetpotato Seed Exchange Systems and Knowledge on Sweetpotato Viral Diseases among Local Farmers in Acholi Sub Region-Northern Uganda. African Journal of Agricultural Research, 13, 2551-2562. https://doi.org/10.5897/AJAR2018.13384

[25] Schreinemachers, P., Balasubramaniam, S., Boopathi, N.M., Ha, C.V., Kenyon, L., Praneetvatakul, S., Sirijinda, A., Tuan, L.N., Srinivasan, R. and Wu, M. (2015) Farmers' Perceptions and Management of Plant Viruses in Vegetables and Legumes in Tropical and Subtropical Asia. Crop Protection, 75, 115-123. https://doi.org/10.1016/j.cropro.2015.05.012

[26] Rahman, M.S., Khatun, M., Rahman M.L. and Haque, S.R. (2018) Assessment of Training Needs on Crop Production for Farmers in Some Selected Areas of Bangladesh. 
Bangladesh Journal of Agricultural Research, 43, 669-690. https://doi.org/10.3329/bjar.v43i4.39165

[27] Fuchs, M. (2008) Les plantes transgéniques et la lutte contre les virus phytopathogènes: Etat de l'art et perspectives. Virologie, 12, 27-37.

[28] Mondedji, A.D., Nyamador, W.S., Amevoin, K., AdéotI, R., Abbey G.A., Ketoh G.K. and Glitho, I.A. (2015) Analyse de quelques aspects du système de production légumière et perception des producteurs de l'utilisation d'extraits botaniques dans la gestion des insectes ravageurs des cultures maraîchères au Sud du Togo. International Journal of Biological and Chemical Sciences, 9, 98-107. https://doi.org/10.4314/ijbcs.v9i1.10

[29] Agboyi, L.K., Djade, K.M., Ahadji-Dabla, K.M., Ketoh, G.K., Nuto, Y. and Glitho, I.A. (2015) Vegetable Production in Togo and Potential Impact of Pesticide Use Practices on the Environment. International Journal of Biological and Chemical Sciences, 9 , 723-736. https://doi.org/10.4314/ijbcs.v9i2.13

[30] Gnago, J.A., Danho, M., Agneroh, T.A., Fofana, I.K. and Kohou, A.G. (2010) Efficacité des extraits de neem (Azadirachta indica) et de papayer (Carica papaya) dans la lutte contre les insectes ravageurs du gombo (Abelmoschus esculentus) et du chou (Brassica oleracea) en Côte d'Ivoire. International Journal of Biological and Chemical Sciences, 4, 953-966. https://doi.org/10.4314/ijbcs.v4i4.63035

[31] Swamy, M.K., Uma, R.S. and Mohd, S.A. (2015) In Vitro Pharmacological Activities and GC-MS Analysis of Different Solvent Extracts of Lantana camara Leaves Collected from Tropical Region of Malaysia. Evidence-Based Complementary and Alternative Medicine, 2015, Article ID: 506413. https://doi.org/10.1155/2015/506413

[32] Füzesi, I., Heil, B. and Kovács, G. (2012) Effects of Wood Ash on the Chemical Properties of Soil and Crop Vitality in Small Plot Experiments. Acta Silvatica et Lignaria Hungarica, 11, 55-64. https://doi.org/10.1515/aslh-2015-0004 